\title{
Morphoanatomy and Chlorophyll of Lettuce Plants Induced by Rhizobacteria
}

\author{
Aline Figueiredo Cardoso, Marcela Cristiane Ferreira Rêgo, Telma Fátima Vieira Batista, \\ Rafael Gomes Viana, Alba Lucia Ferreira de Almeida Lins, Gisele Barata da Silva \\ (Corresponding Author) \\ Plant Protection Laboratory, Institute of Agrarian Sciences, Federal Rural University of \\ Amazon, CEP.066.077-830.Belém, Pará, Brazil
}

$\begin{array}{lrr}\text { Received: August 6, } 2019 & \text { Accepted: Sep. 15, } 2019 \quad \text { Published: Sep. 22, } 2019 \\ \text { doi:10.5296/jas.v7i4.15218 } & \text { URL: https://doi.org/10.5296/jas.v7i4.15218 }\end{array}$

\begin{abstract}
Lettuce is a consumed crop in the world, and increased yield is a desirable trait, and can be realized with the use of biopromotors, already described in many cultures. The objective of this work was to test the ability of two rhizobacterial isolates P. fluorescens (BRM-3211) and B. pyrrocinia (BRM-3213) to promote anatomical and growth changes in lettuce plants in the seedling stage. The increments promoted by $B$. pyrrocinia were smaller when using $P$. fluorescens. The BRM-32111 isolate, promoted increases in leaf area of 133\%, 31\% and $307 \%$ of fresh shoot and root mass, also increased $51 \%$ and $143 \%$ of aerial and root dry mass. The plants inoculated with BRM-32111 increased in $100 \%$ and $68 \%$ of the aerial part and radicular compared to the control treatment, and induced alterations in the anatomical characteristics in the root in $74 \%$ in the radicular diameter, $20 \%$ of the thickness of the cortex, $67 \%$ of the exoderme and $171 \%$ of the endoderm. In the leaf anatomy, BRM 32111 increased by $18 \%$ in the parenchyma expansion, $56 \%$ in the number of parenchyma cell layers, $122 \%$ adaxial endoderm, $23 \%$ epidermis, $174 \%$ beam expansion, $37 \%$ when compared to control. In this way the use of BRM-32111 influences the growth and morphology of lettuce seedlings.
\end{abstract}

Keywords: Pseudomonas fluorescens, Burkholderia pyrrocinia, biopromoter

\section{Introduction}

The need for increased food production based on sustainable agriculture has been addressed in several studies, so the application of biopromotors in agriculture has become an important resource, with the reduction or total absence of fertilizer applications, besides the increase and quality in production (Shrivastava; Kumar, 2015; Viana, 2015). The use of rhizobacteria in lettuce (Lactuca sativa L.) may favor the highest growth and consequently higher production, which is one of the most consumed vegetables, mainly because it is rich in fiber and vitamins that complement the basic diet (Sala; Costa, 2012; Gupta; Dolma; Khan, 2014). 
Rhizobacteria are being widely used in different crops, such as rice, maize, and watermelon (Souza, et al., 2013; Agbodjato et al., 2016; Pais et al., 2016), as it has the ability to colonize the roots of plants modulating changes in root architecture and enlargement of anatomical cells, thereby promoting plant growth from greater root development, combined with increased synthesis of auxins and cytokines, which may result in greater efficiency in nutrient absorption, greater fixation of nitrogen, and consequently energy for metabolic processes fundamental for plant development (Hayat et al, 2010: Ashraf et al., 2013; Ahemad; Kibret, 2014; Rego et al., 2014).

In this study, the objective was to obtain rhizobacterial lettuce interaction responses, describing the anatomical, morphological and changes in chlorophyll content=

\section{Method}

The experiments were carried out in the Laboratory of Plant Protection (LPP) and nursery at the Federal Rural University of Amazonia in Belém, Pará in Brazil.

\subsection{Preparation and Inoculation of Isolates}

The bacterial suspension of Pseudomonas fluorescens (BRM-3211) and Burkholderia pyrrocinia (BRM-3213) was prepared according to Filippi et al., (2011), besides identified by the same authors. Lettuce seeds were submerged in the suspension for 24 hours under agitation at $114 \mathrm{rpm}$. These isolates are from rice rhizosphere and are part of the microorganism collection of the Plant Protection Laboratory of the Federal Rural University of Amazônia-UFRA.

\subsection{In Vitro Selection}

In gearbox box $(250 \mathrm{~mL}), 25$ lettuce seeds were seeded under filter paper moistened with sterile water, three treatments (P. fluorences (BRM-3211), B. pyrrocinia (BRM-3213)), and control-water), with four replications. The boxes were kept in a germination chamber at $28^{\circ}$ C, under white light with a 12-hour photoperiod and light intensity of $290 \mu \mathrm{mol} \cdot \mathrm{m}^{-2} \cdot \mathrm{s}^{-1}$ and humidity of $80 \%$ RH (Catão et al., 2014). Germination was evaluated after 24, 48, 72 and 96 hours (Pacheco Júnior et al., 2013), was evaluated according to Labouriau and Valadares (1976), the germination rate, besides the germination speed index (Maguire, 1962). At seven days of age the seedlings were evaluated, the length and fresh mass of shoot and root, respectively. After drying in a forced air circulation oven at $60^{\circ} \mathrm{C}$ for 48 hours, the dry mass was evaluated (Moreira et al., 2008)

\subsection{Vegetation House}

Five seeds per polyethylene pot $(300 \mathrm{~mL})$ were seeded in Ferrasol soil with the following characterization: $\mathrm{pH}$ (water) 4.2; $18.80 \mathrm{~g} \mathrm{dm}^{-3}$ M.O .; $2 \mathrm{mg} \mathrm{dm}^{-3}$ of P; $4 \mathrm{mg} \mathrm{dm}^{-3} \mathrm{~K} ; 18 \mathrm{mg}$ $\mathrm{dm}^{-3} \mathrm{Na} ; 0.05 \% \mathrm{~N} ; 0.2 \mathrm{mmol}$ of $\mathrm{dm}^{-3} \mathrm{Ca} ; 0.3 \mathrm{mmol} \mathrm{dm}{ }^{-3} \mathrm{Ca}+\mathrm{Mg}$; At the seventh day after sowing (AS), one plant was removed by potting, under average daytime air temperature of $27^{\circ} \mathrm{C}$, relative humidity of $74 \%$ and light intensity of $1300 \mu \mathrm{mol} . \mathrm{m}^{-2} \cdot \mathrm{s}^{-1}$ (HOBO Data Logger). Two treatments (P. fluorescens -BRM-3211 and control-sterile water) were used, with seven replicates. 


\subsection{Growth Analysis}

The analyzes occurred at 28 days after sowing, including the period of germination, maternity and Pre-Growth. It was determined the area by non-destructive method, using the product of the main vein length and the maximum leaf width, multiplied by the correction factor 0.66 proposed by Pereira et al., (2003), followed by collection and mass evaluation fresh and dry, with precision analytical balance weighing. Then, the plants were dried in a forced circulation air oven with temperature of $60^{\circ} \mathrm{C}$ for 48 hours, followed by weighing dry mass root system of the aerial part (Moreira et al., 2008).

\subsection{Relative Chlorophyll Content}

The chlorophyll content was estimated using a portable meter (SPAD-502, Konica Minolta Sensing, INC. Japan), at 28 days AS, evaluating the second leaf of each plant.

\subsection{Anatomical Study of Root and Leaf}

The leafs and roots were fixed in FAA70 (formaldehyde, glacial acetic acid, and ethanol 70\%) for 72 hours and placed into $70 \%$ ethanol (Johansen, 1940). Three leaves per replicate were used for the anatomical analysis, in which transverse sections were made in the region of the middle third through the inclusion of samples in synthetic resin. The blocks were transversely cut in a rotary microtome, were stained with toluidine blue. These were then fixed between blade and cover slipping. The analyzed variables for the sections were the parenchyma expansion, number of parenchymal cell layers, vascular bundle expansion, leaf blade diameter, The roots were cut by hand in the region near the stem, the cuts were clarified in a bleach solution, stained in Astrablau (Braga, 1977). Root diameter expansion, cortex expansion, exoderm expansion and leaf endoderm expansion, parenchymal expansion, number of parenchymal cell layers were analyzed. Variables were measured using the Anati Quant 2® UFV program (Aguiar et al., 2007).

\subsection{Experimental Design and Statistical Analysis}

The data obtained in the selection in vitro were submitted to an analysis of variance and compared by the Duncan test the data obtained in the greenhouse were compared by the test, software assistant 7.7.

\section{Results}

\subsection{Selection of Rhizobacteria}

Germination of lettuce seeds inoculated with rhizobacteria was observed 48 hours after sowing, and was verified by the increase of germination speed index, however in the control treatment it was observed only at 72 hours. However, there was no difference between treatments at four days after seed sowing (Figure 1A-B). 

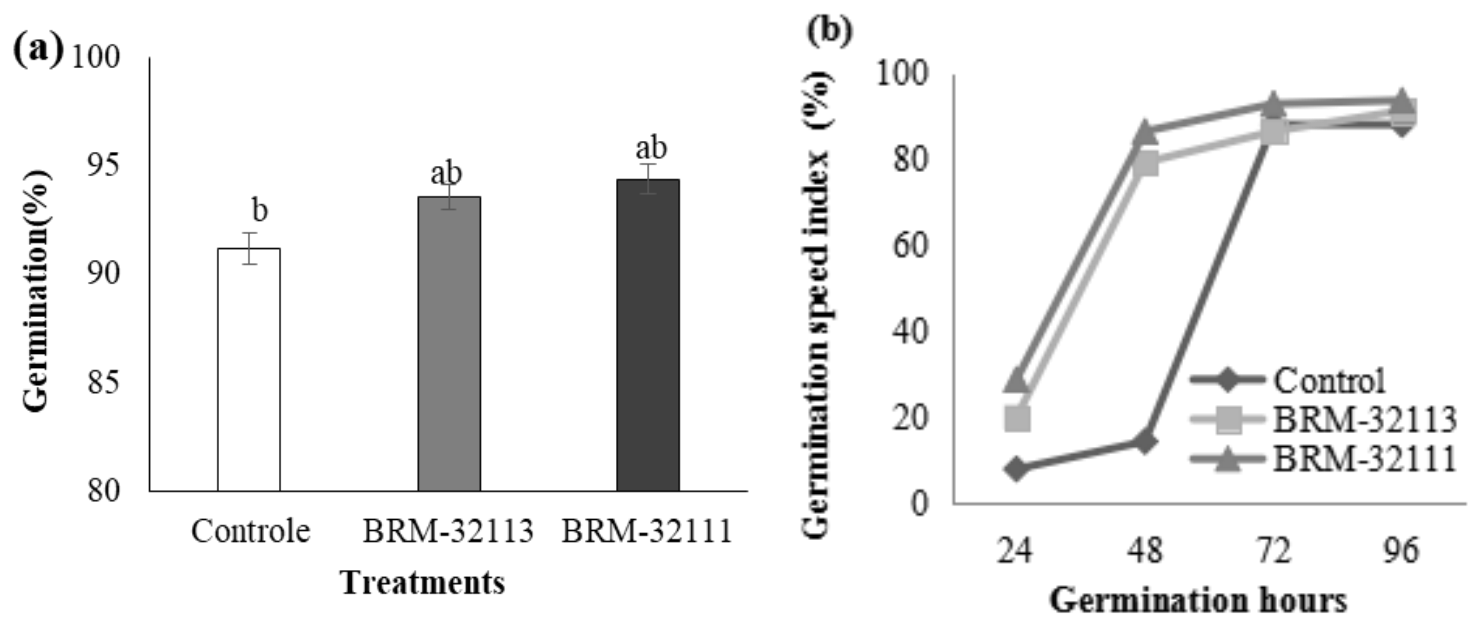

Figure 1. Germination rate (\%) (a) and germination speed index (b) at four days after sowing of un inoculated (control) seedlings and inoculated with Burkholderia pyrrocinia (BRM-32113) and Pseudomonas fluorenscens (BRM-32111). Bars followed by the same lowercase letters did not differ between treatments (Duncan, $\mathrm{p}<0.05$ )

The seedlings inoculated with P. fluorenscens showed an increase in the fresh mass of aerial part in $31 \%$, and root in $307 \%$, and aerial part dry matter in $51 \%$ and $143 \%$, in addition to $100 \%$ and $68 \%$ in length gain of aerial and radicular compared to the control treatment (Figure $2 \mathrm{AF}$ ).

(a)

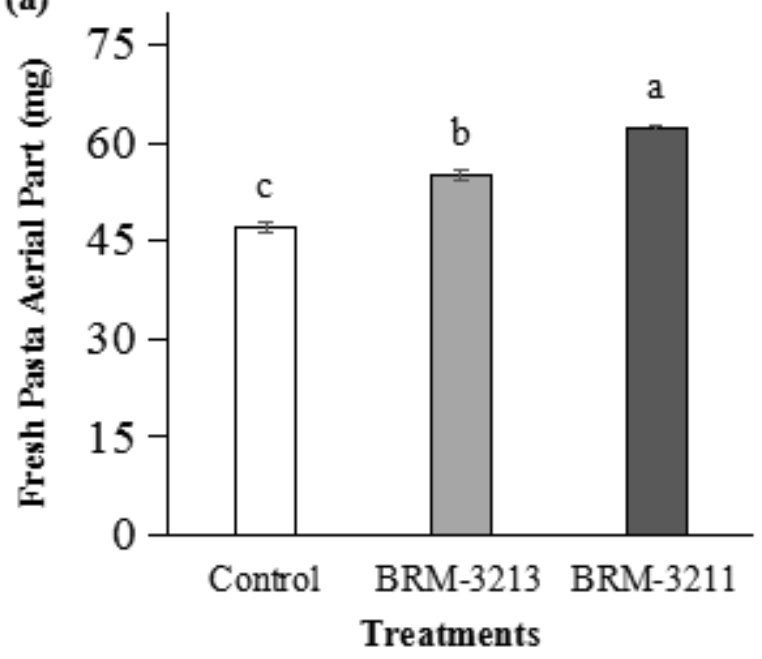

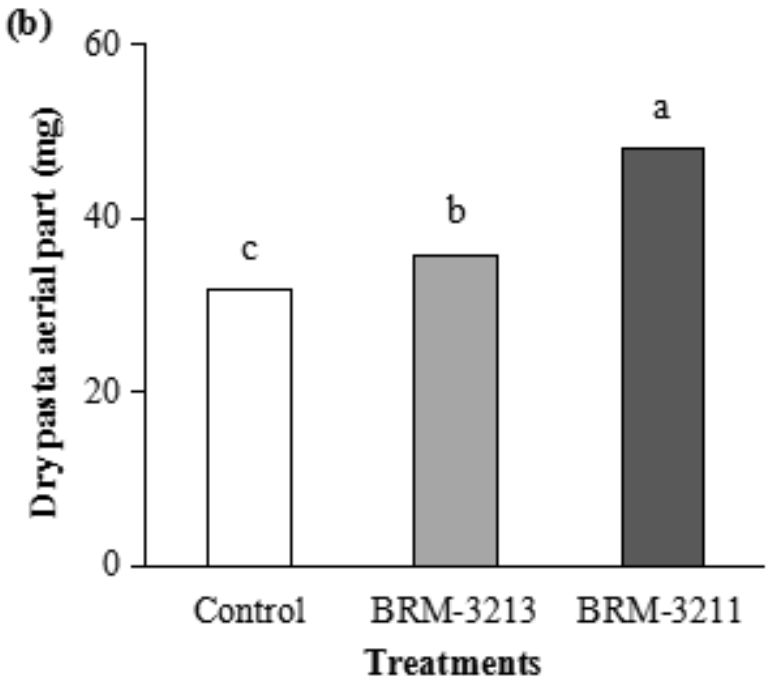



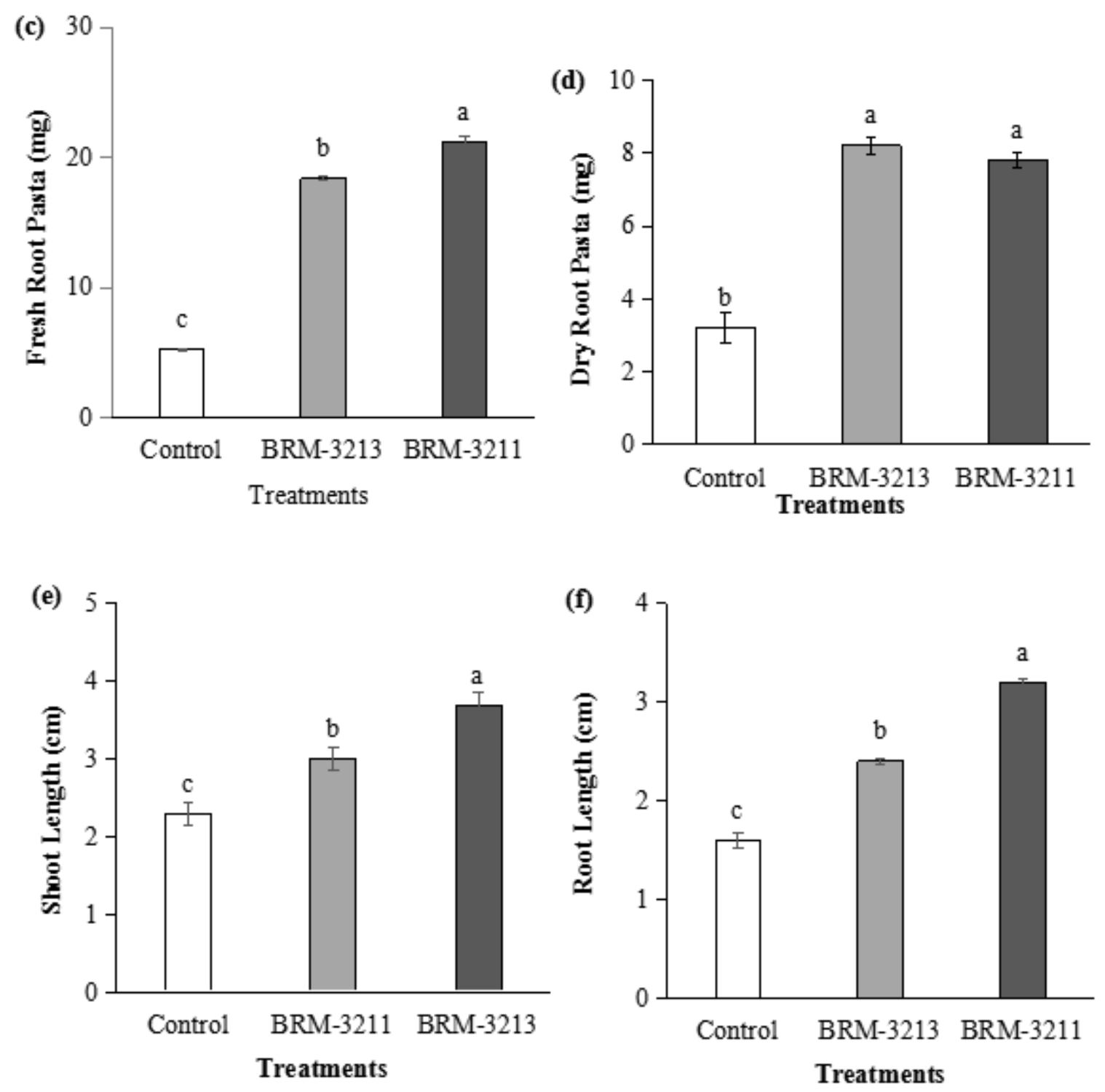

Figure 2. Fresh aerial mass (a), fresh root mass (b), aerial dry mass (c), root dry mass (d), shoot length (e) and root (f) (control) and inoculated with B. pyrrocinia (BRM-32 113) and $P$. fluorescens (BRM-32 111). Bars followed by the same lowercase letter did not differ between treatments (Duncan, $\mathrm{p}<0.05$ ) and standard error $(\mathrm{p}<0.05), \mathrm{n}=7$

\subsection{Vegetation House}

Lettuce plants inoculated with BRM-32111 showed an increase in all growth variables. The fresh mass increment of aerial and radicular was $20 \%$ and $197 \%$, aerial part dry mass and radicular, in $146 \%$ and $75 \%$, respectively (Figure 3A-D). 

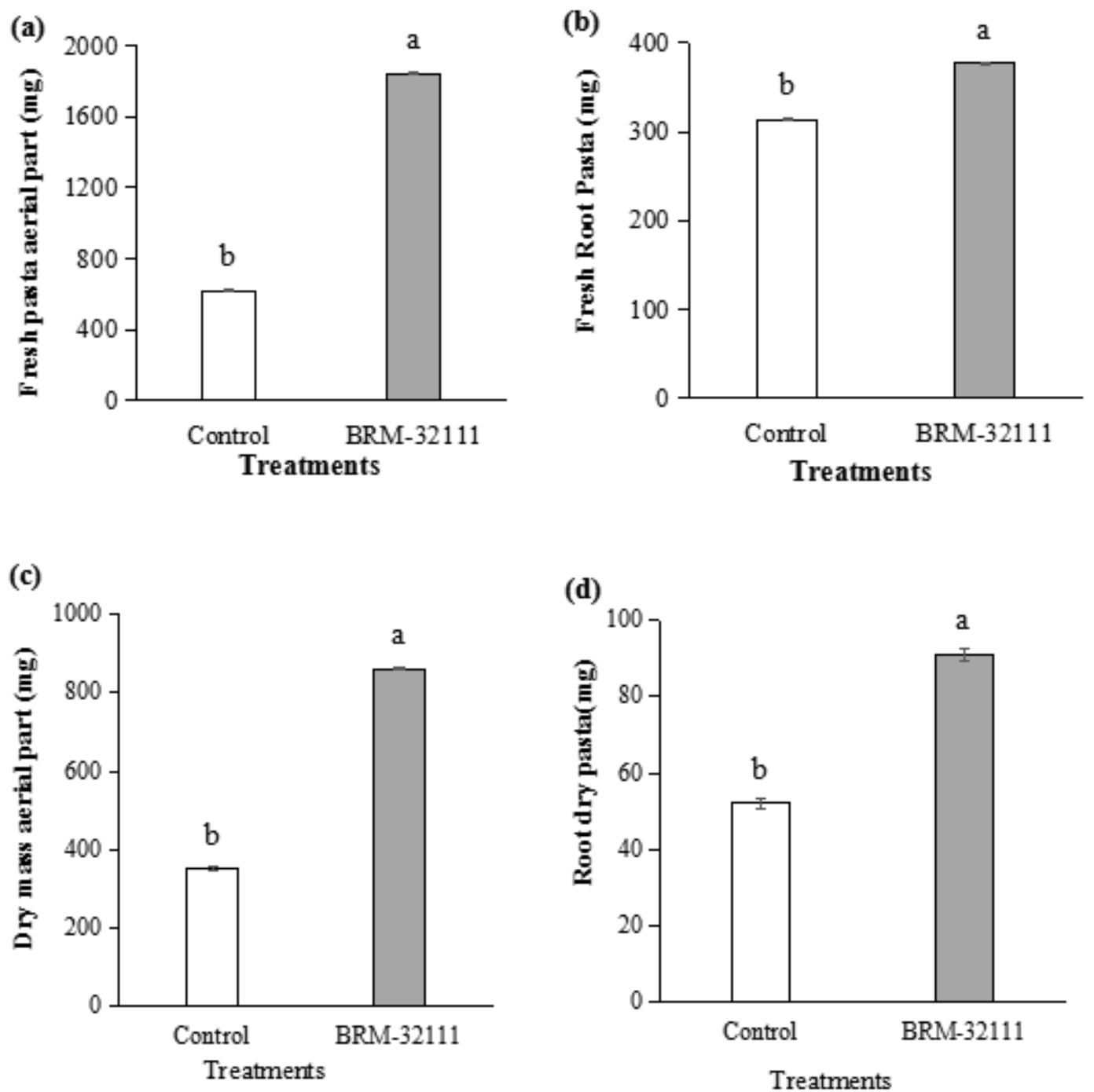

Figure 3. Fresh aerial part (a), Fresh root mass (b), Dry mass aerial part (c), Root dry pass (d), lettuce seedlings from un inoculated seeds (control), seeds inoculated with Burkholderia pyrrocinia (BRM 32113) and $P$ :fluorescens (BRM 32111). Bars followed by the same lowercase letters did not differ between treatments (Duncan, $\mathrm{p}<0.05$ ), $\mathrm{n}=7$

Plants treated with BRM 32111 increased leaf area by 133\% compared to control at 28 days after sowing (Figure 4A). Lettuce plants inoculated with BRM 32111 had an increase in chlorophyll content in the SPAD in relation to the control. Regarding the control plants (without fertilization), the plants inoculated with BRM 32111 the increase was in 18\% relative chlorophyll content (SPAD) (Figure 4B). 

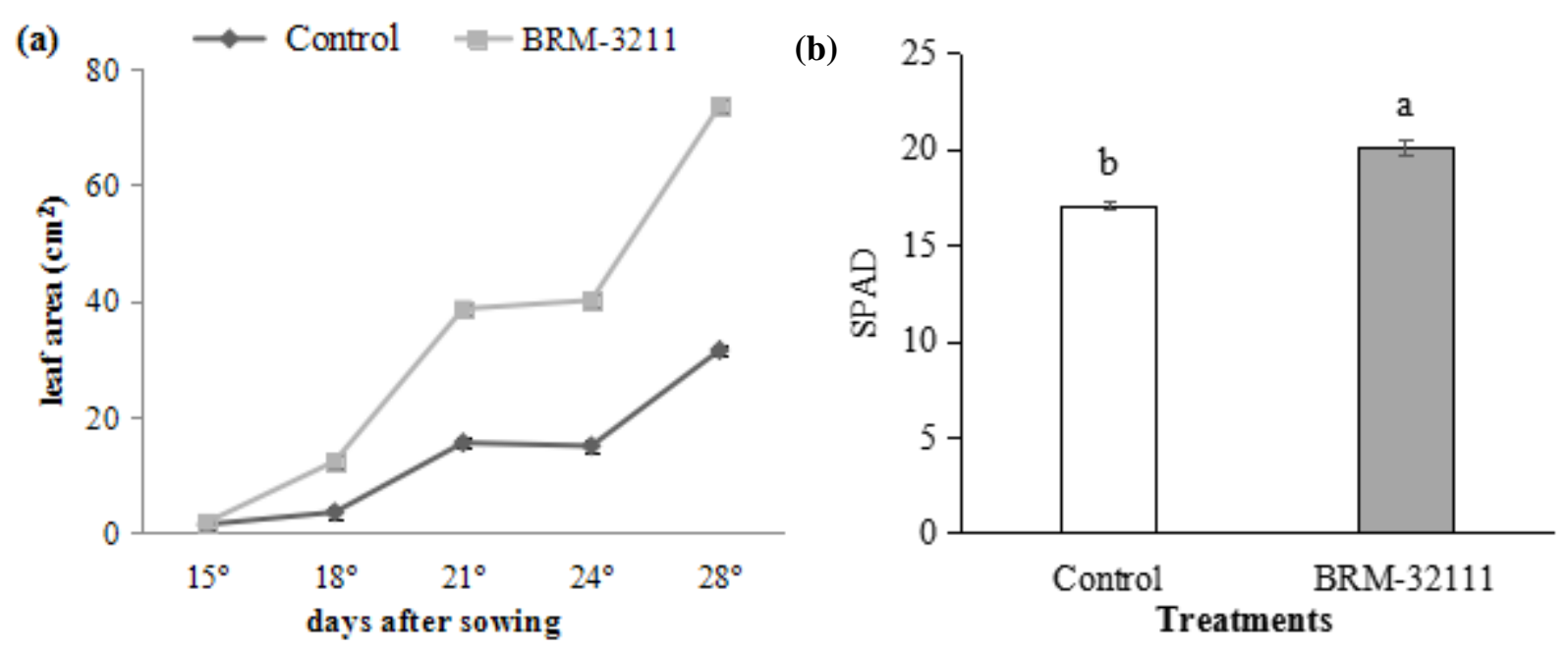

Figure 4. Leaf area and SPAD value. Leaf area $\mathrm{cm} 2$ of (a) and SPAD (b) value of plants not inoculated and inoculated with P. fluorescens (BRM32111). Bars followed by the same lowercase letters did not differ between treatments (Duncan, $\mathrm{p}<0.05$ ), $\mathrm{n}=7$

BRM 32111 induced alterations in the anatomical characteristics in root and leaf of lettuce. The inoculation increased by $74 \%$ in the root diameter, $20 \%$ of the cortex, $67 \%$ of the exoderm and $171 \%$ of the endoderm, compared to control plants. The foliar anatomy BRM 32111 showed an increase of $18 \%$ in the parenchyma expansion, $56 \%$ in the number of parenchyma cell layers, $122 \%$ adaxial endoderma, 23\% epidermis, 174\% beam expansion, $37 \%$ distance between the bundles, when compared to the control (Figures, 5, 6 and 7). 

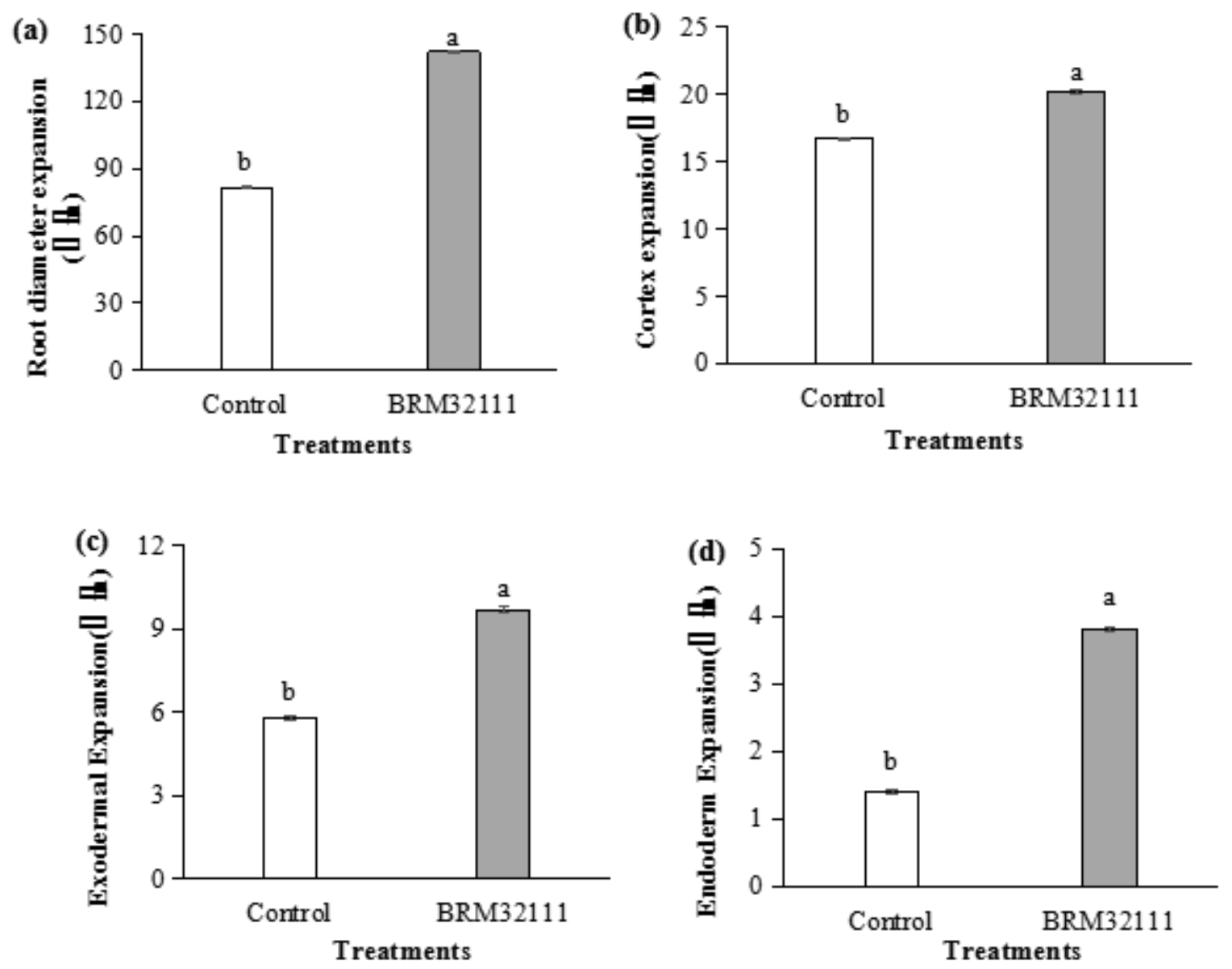

Figure 5. Expansion of radicular diameter (a), Expansion of cortex (b), Expansion of exoderma (c) and Expansion of endoderm (d). Determined from roots were plants not inoculated and inoculated with P. fluorescens - BRM-32111. Bars followed by the same capital letter do not differ between plants with the same test $t$ inoculation $(p<0.05)$
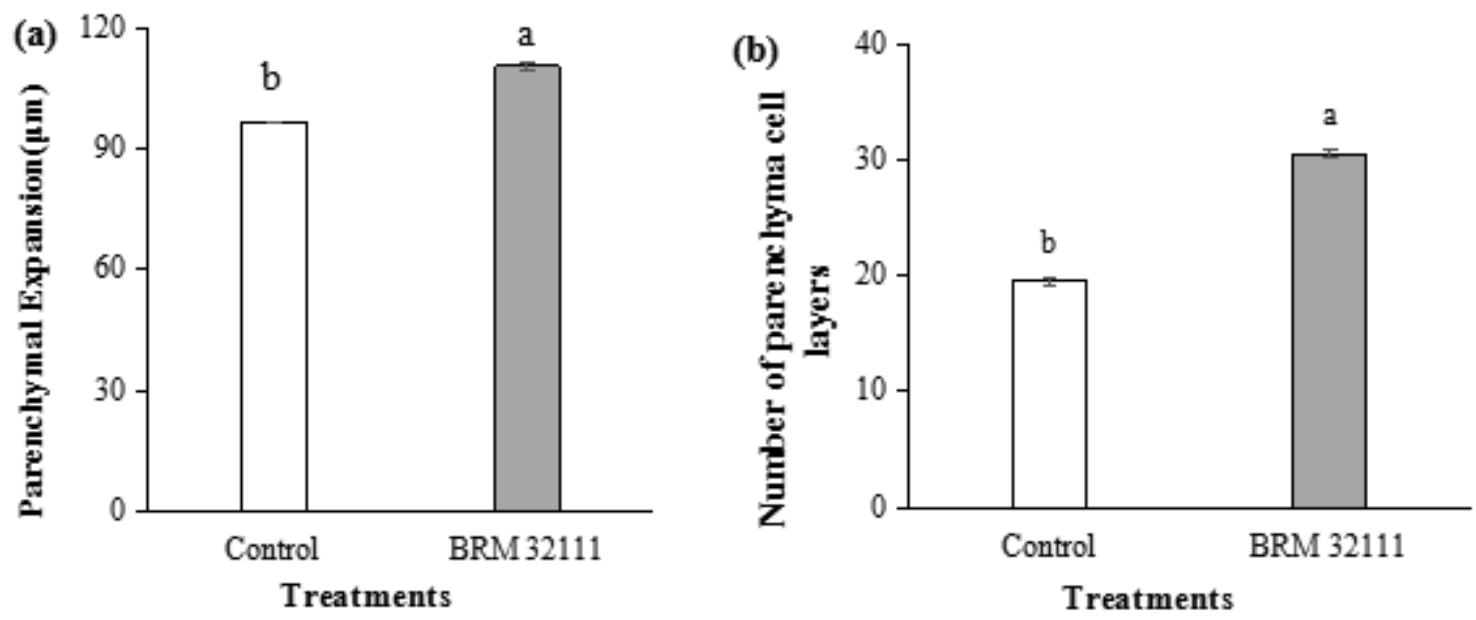


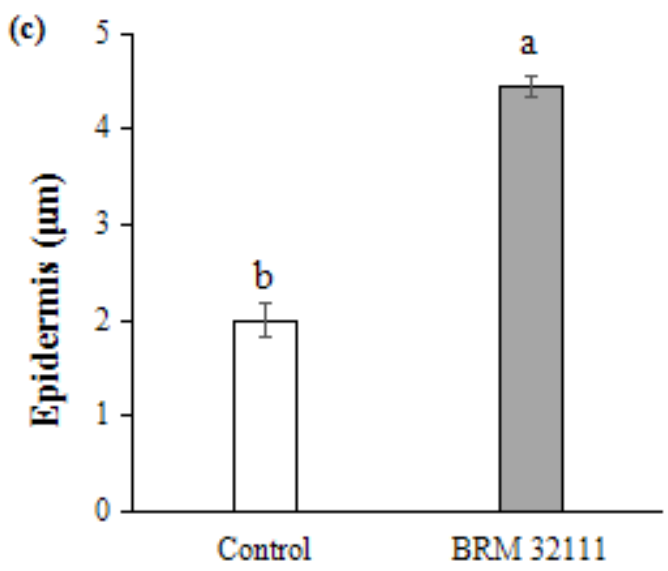

Treatments

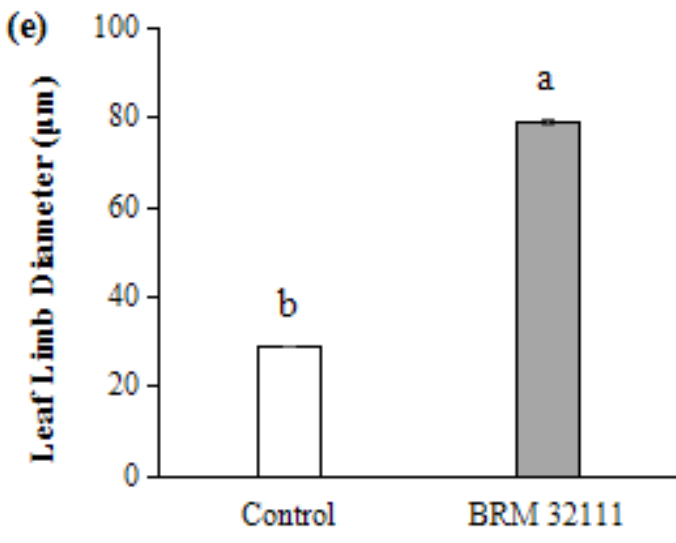

Treatments
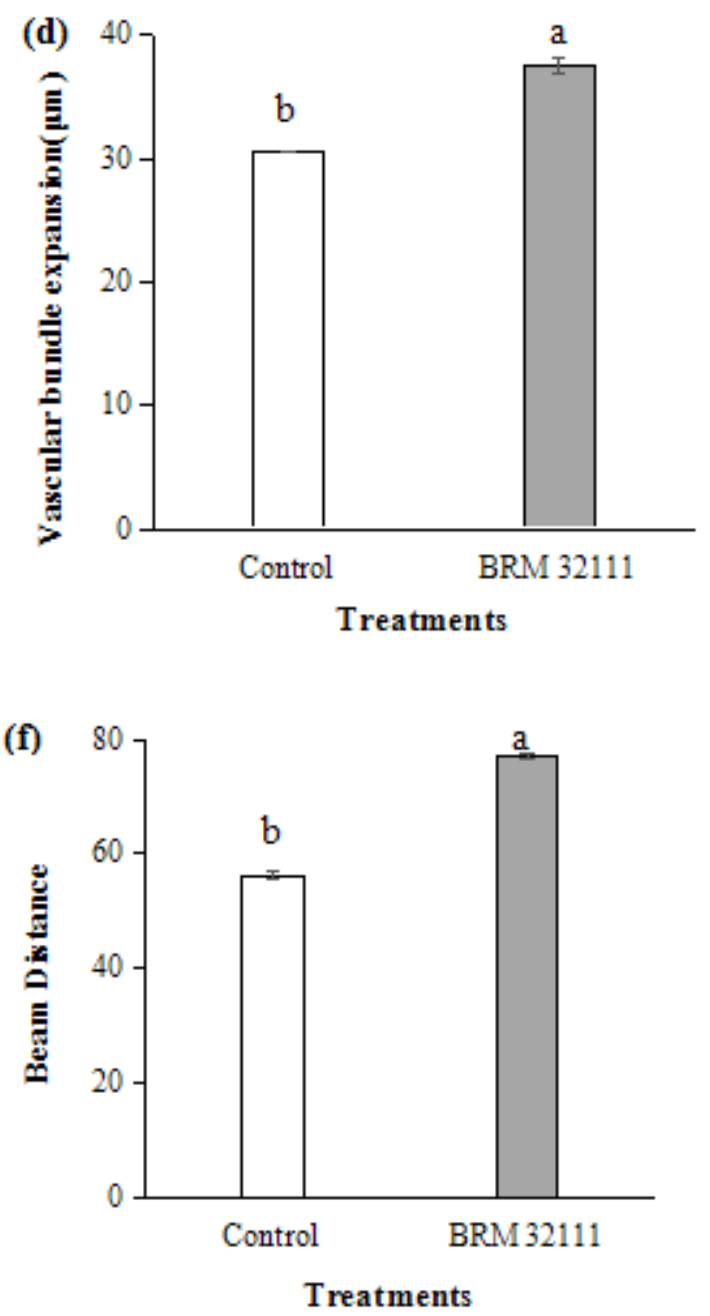

Figure 6. Parenchyma expansion (a), number of layers of parenchyma cells (b), Expansion of epidermis (c), Vascular bundle expansion $(\mu \mathrm{m})(\mathrm{d})$, Leaf Limb Diameter $(\mu \mathrm{m})(\mathrm{e})$ and beam distance (f), the cross section on lettuce leaves at 28 after sowing. Determined from plants un inoculated and inoculated with P. fluorescens - BRM-32 111. Bars followed by the same capital letter do not differ between plants with the same $t$ test inoculation $(p<0.05)$

(A)

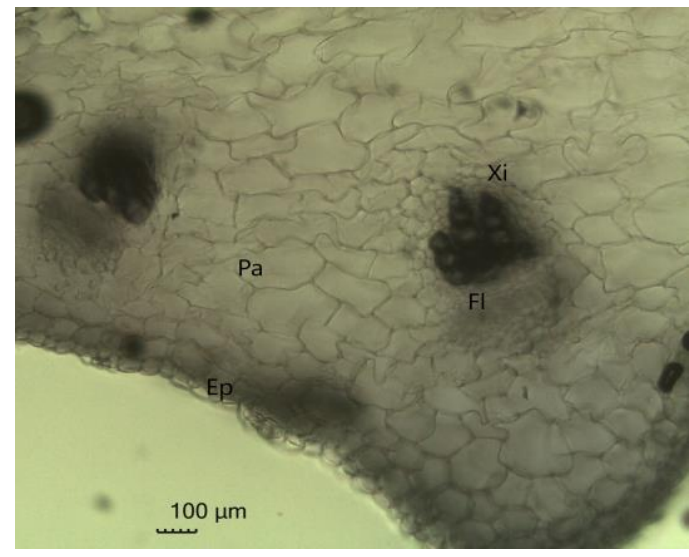

(B)

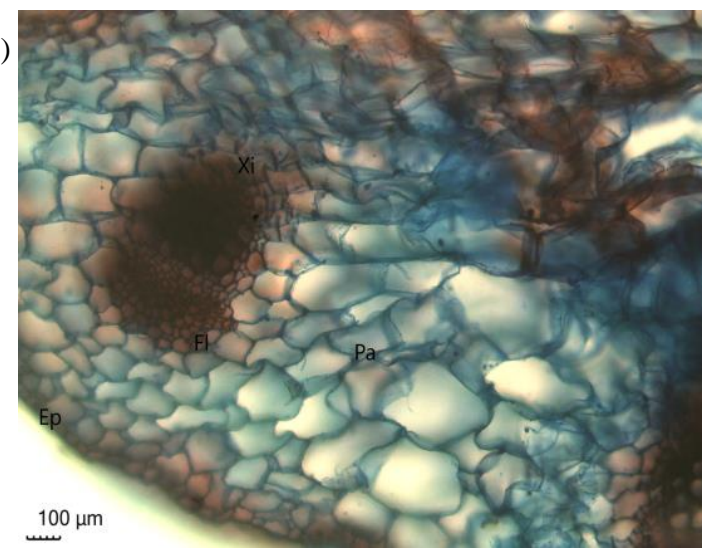

Figure 7. Cross section of control plant leaf (a), and cross section of plant leaf BRM 32111. (*)Epidermis (Ep), Parenchyma (Pa) Xylem (Xi) and Phloem (Fl) 


\section{Discussion}

The rhizobacterium $P$. fluorescens (BRM 32111) induced increase in lettuce growth and anatomical differences. This isolate of rhizobacteria originates from the rice rhizosphere, and in this culture was recorded as a growth promoter (Filippi et al., 2011; Rêgo et al., 2014). There are other isolates of Pseudomonas previously recorded as growth promoters in lettuce (Ahmed et al., 2015, Kumar et al., 2016). The gain in fresh mass and leaf area in lettuce plants induced by $P$. fluorescens is the result of greater emphasis of the present study, since the final product commercialized is the leaves, besides guaranteeing seedlings with greater vigor, quality, quantity and with better performance for transplanting and final production. In the present BRM 32111 study, stimulated germination speed and root growth, this PGPR $x$ root interaction may result in modifications in root architecture such as increased lateral root formation, length and number of root hairs (Schlindwein et al. 2008; Kozusny-Andreani, Agiado, Andreani-Junior, 2014). In addition, from which pseudomonas may have provided the highest modulating signaling and gene expression of the genes related to indole-3-acetic acid (AIA) (Spaepen; Vanderleyden, 2011), which is the most abundant endogenous auxin that has roles in stem elongation and root growth (Zhao et al., 2012). Another hormone involved in the induction of growth is ethylene, which the higher the AIA / ethylene ratio, promotes greater root growth. On the other hand, PGPRs act directly or indirectly in the AIA / Ethylene ratio, either by producing the enzyme ACC deaseminase, or by influencing the metabolic pathway of this enzyme with another secondary molecule (Glick, 2012), thus hydrolyzing the ACC compound that is the main precursor of ethylene in the plant, in ammonia and $\alpha$-ketobutyrate, with lower ethylene stimulation and higher AIA production (Glick, 2014). In the present study, the genus Pseudomonas differed from the genus Bulkolderia in relation to the growth gain, which can be attributed to the differential induction of the hormonal balance AIA / ethylene.

The anatomical root constitution obtained in this work may be desirable, since cortex occupies most of the area in the primary growth in many roots, formed by parenchyma cells where the cells of the endoderm are allocated (Esau, 1975), these in turn are divided several times and differentiate to form the lateral root that emerge from the primary root in the zone of differentiation (Malamy; Benfey, 1997; Lundberg et al., 2012; Sessitsch et al., 2012). In this way, Pseudomonas fluorescens positively affected post-embryonic development may have altered cell division and root differentiation, which resulted in greater root development.

The increase of the leaf area induced by $P$. fluorescens in lettuce, can be attributed to the greater root development promoted by the rhizobacterium, which provided the plant, increased nutrient absorption and translocation (Saia et al., 2015), increased nitrogen uptake, and increased the synthesis of proteins and enzymes (Mia; Shamsuddin and Mahmood, 2010).

The effect from the BRM 32111 inoculation in lettuce seeds, obtaining a drastic increase of root biomass and leaf area was evidenced in rice, where plants treated with the isolates of Pseudomonas synxantha and Bacillus sp. In the present study, it was observed that the nutrient content of the plants increased by $70 \%$, due to the greater nutrient uptake by the 
plants (Souza-Júnior et al., 2011). Pereira and Castro (2014) in maize plants have verified that increased plant growth is related not only to $\mathrm{P}$ solubilization provided by rhizobacteria, but also to increased AIA and pseudomonas-induced ACC-deaminase activity. This relationship of the PGPRs with the plant is established expression of differentially expressed genes (Srivastava et al., 2012). Pseudomonas sp. indirectly or secondarily, expresses the genes that encode nitrogen (NifHDK) responsible for nitrogen fixation; quinone (pqqBCDEFG) contributes to the phosphate solubilization, and also Pseudomonas and the 1-aminocyclopropane-1-carboxylate (ACC) deaminase (acdS) gene (Xuemei et al., 2013). The higher aerial development of lettuce plants inoculated with Pseudomonas sp. may have positive relation to nitrogen concentration in the leaves and the value of Spad, as a function of the role of nitrogen in the synthesis of chlorophyll (Debaeke et al., 2006; Teixeira Filho et al.,2010). Bacteria of the genus Pseudomonas sp. have a nitrogenase enzyme complex that act to reduce atmospheric nitrogen to ammonia, increasing their availability, so $\mathrm{N}$ is used in different syntheses besides chlorophylls, amino acids, DNA, RNA (Hayat et al., 2010; Bulgarelli et al., 2013). P. fluorescens F11320, expressed (ppdC) of the indole-3-pyruvate pathway for the synthesis of indole-acetic acid (IAA).

The leaf is considered a vital organ, to obtain energy for the metabolic processes, in this work the greater gain in fresh mass and leaf area provided by pseudomonas, also contributed to an increase of anatomical cells. The increase in the leaf limbus provided by the inoculation with BRM 32111 can reflect in the greater use of the light rays, water and photosynthesis, once also that there was, the increase of the epidermal cells, that is a system of coating fabric, protection against desiccation, influences the gas exchange in addition to being able to promote the plant greater mechanical protection, mainly against pathogens, which together with the greater parenchyma cell expansion can reflect in a larger thickness of the leaf of lettuce, culminating in less loss of water, and temperature regulation (Yeats and Rose, 2013; Ramos et al., 2015; Verboven et al., 2015). The cytokinins and auxin may be important regulators of cell specification and root proliferation, but auxin may also be related to cell elongation and changes in the vascular bundle pattern (Stahl and Simon, 2010; Zhang and Rongming, 2014). At responses to nitrogen in lettuce showed that plantings enriched with the element, besides providing greater leaf development, can influence the total number of epidermal cells per leaf. In this work pseudomonas influenced positively these characteristics, mainly by its commercialization, thus, all the variables influenced by $P$. fluorescens in the present study, contributed to a higher biomass of lettuce seedlings, this effect is attributed to the several modes of action of rhizobacteria previously described, from greater root development, greater nutrient uptake and translocation to the development of aerial part of lettuce plants. The increase in biomass by Pseudomonas has already been described and attributed, yet the production of hormones (Liu et al., 2013).

In this way, we showed that $P$. fluorescens is a growth promoter in lettuce because it induces gain in all the morpho physiological parameters. In the lettuce was verified mainly the gain in leaf area that is the product with greater commercial value, thus creating future perspectives for the use of this bacterium in the management of the lettuce production, aiming the sustainable agricultural production. 


\section{References}

Agbodjato, N. A., Noumavo, P. A., Adjanohoun, A., Agbessi, L., \& Baba-Moussa, L. (2016). Synergistic effects of plant growth promoting rhizobacteria and chitosan on in vitro seeds germination, greenhouse growth, and nutrient uptake of maize (Zea mays L.). Biotechnology research international. Int. 2016, 1. https://doi.org/10.1155/2016/7830182

Aguiar, T. V., Sant'anna-Santos, B. F., Azevedo, A. A., \& Santos, R. F. (2007). Anati Quanti: Software de análises quantitativas para estudos em Anatomia Vegetal. Planta Daninha, 25, 649-659. https://doi.org/10.1590/S0100-83582007000400001

Ahemad, M., \& Kibret, M. (2014). Mechanisms and applications of plant growth promoting rhizobacteria: current perspective. Journal of King saud University-science, 26(1), 1-20. https://doi.org/10.1016/j.jksus.2013.05.001

Ahmed, S., \& Ikram, S. (2015). Chitosan \& its derivatives: a review in recent innovations. International Journal of Pharmaceutical Sciences and Research, 6(1), 14-30. https://doi.org/10.13040/IJPSR.0975-8232

Ashraf, M. H. P. J. C., \& Harris, P. J. (2013). Photosynthesis under stressful environments: an overview. Photosynthetica, 51(2), 163-190. https://doi.org/10.1007/s11099-013-0021-6

Braga, M. M. N. (1977). Anatomia foliar de Bromehaceae da Campina. Acta Amazonica, 7(3), 5-74. https://doi.org/10.1590/1809-43921977073s005

Bulgarelli, D., Schlaeppi, K., Spaepen, S., Van Themaat, E. V. L., \& Schulze-Lefert, P. (2013). Structure and functions of the bacterial microbiota of plants. Annual review of plant biology, 64, 807-838. https://doi.org/10.1146/annurev-arplant-050312-120106

Catão, H. C. R. M., Gomes, L. A. A., Santos, H. O. D., Guimarães, R. M., Fonseca, P. H. F., \& Caixeta, F. (2014). Aspectos fisiológicos e bioquímicos da germinação de sementes de alface em diferentes temperaturas. Pesquisa Agropecuária Brasileira, 49(4), 316-322. https://doi.org/10.1590/S0100-204X2014000400010

de Souza Júnior, I. T., Moura, A. B., Schafer, J. T., Corrêa, B. O., \& Gomes, C. B. (2011). Biocontrole da queima-das-bainhas e do nematoide-das-galhas e promoção de crescimento de plantas de arroz por rizobactérias. Pesquisa Agropecuária Brasileira, 45(11), 1259-1267. https://doi.org/10.1590/S0100-204X2010001100005

de Souza, R., Beneduzi, A., Ambrosini, A., Da Costa, P. B., Meyer, J., Vargas, L. K., ... Passaglia, L. M. (2013). The effect of plant growth-promoting rhizobacteria on the growth of rice (Oryza sativa L.) cropped in southern Brazilian fields. Plant and soil, 366(1-2), 585-603. https://doi.org/10.1007/s11104-012-1430-1

Debaeke, P., Rouet, P., \& Justes, E. (2006). Relationship between the normalized SPAD index and the nitrogen nutrition index: application to Durum Wheat. Journal of Plant Nutrition, 29, 75-92. https://doi.org/10.1080/01904160500416471

Esau, K. (1965). Plant anatomy, 2nd edition. New York: John Wiley and Sons, p 767. 


\section{Macrothink}

Filippi, M. C. C., Da Silva, G. B., Silva-Lobo, V. L., Côrtes, M. V. C., Moraes, A. J. G., \& Prabhu, A. S. (2011). Leaf blast (Magnaporthe oryzae) suppression and growth promotion by rhizobacteria on aerobic rice in Brazil. Biological Control, 58(2), 160-166.

https://doi.org/10.1016/j.biocontrol.2011.04.016

Glick, B. R. (2014). Bacteria with ACC deaminase can promote plant growth and help to feed the world. Microbiological research, 169(1), 30-39.

https://doi.org/10.1016/j.micres.2013.09.009

Glick, B. R. (2012). Plant growth-promoting bacteria: mechanisms and applications New York: Hindawi Publishing Corporation; Scientifica, 33. https://doi.org/10.6064/2012/963401

Gupta, A. J., Dolma, T., \& Khan, A. A. (2014). Component analysis of lettuce (Lactuca sativa L.) for horticultural traits and yield. Progressive Horticulture, 46(1), 85-88.

Hayat, R., Ali, S., Amara, U., Khalid, R., \& Ahmed, I. (2010). Soil beneficial bacteria and their role in plant growth promotion: a review. Annals of microbiology, 60(4), 579-598. https://doi.org/10.1007/s13213-010-0117-1

Jarak, M., Mrkovački, N., Bjelić, D., Joscaron, D., Hajnal-Jafari, T., \& Stamenov, D. (2012). Effects of plant growth promoting rhizobacteria on maize in greenhouse and field trial. African Journal of Microbiology Research, 6(27), 5683-5690.

https://doi.org/10.5897/AJMR12.759

Johansen, D. A. (1940). Plant microtechnique. McGraw-Hill Book Company, Inc: London; $530 \mathrm{p}$.

Júnior, F. P., da Silva, J. B., da Silva Negreiros, J. R., Alves, C. Z., \& de Cavalho, M. A. C. (2016). Avaliação do potencial fisiológico de sementes de pimenta longa. Revista De Ciênciasagroambientais, 13(2). https://doi.org/10.1590/S1806-66902013000200015

Kozusny-Andreani, D. I., \& Junior, R. A. (2014). Colonização rizosférica e promoção do crescimento por rizóbios em mudas de alface. Nucleus, 11(2), 443-452.

https://doi.org/10.3738/1982.2278.1108

Kumar, M., Mishra, S., Dixit, V., Kumar, M., Agarwal, L., Chauhan, P. S., \& Nautiyal, C. S. (2016). Synergistic effect of Pseudomonas putida and Bacillus amyloliquefaciens ameliorates drought stress in chickpea (Cicer arietinum L.). Plant signaling \& behavior, 11(1), e1071004. https://doi.org/10.1080/15592324.2015.1071004

Kundan, R., Pant, G., Jadon, N., \& Agrawal, P. K. (2015). Plant growth promoting rhizobacteria: mechanism and current prospective. J Fertil Pestic, 6(2).

https://doi.org/9.10.4172/2471-2728.1000155

Labouriau, L. G., \& Valadares, M. B. (1976). On the germination of seeds of Calotropis procera. Anais da Academia Brasileira de Ciências 48, 174-186.

https://doi.org/10.12702/iii.inovagri.2015-a224 
Liu, F., Xing, S., Ma, H., Du, Z., \& Ma, B. (2013). Plant growth-promoting rhizobacteria affect the growth and nutrient uptake of Fraxinus americana container seedlings. Applied microbiology and biotechnology, 97(10), 4617-4625.

https://doi.org/10.1007/s00253-012-4255-1

Lundberg, D. S., Lebeis, S. L., Paredes, S. H., Yourstone, S., Gehring, J., Malfatti, S., ... Edgar, R. C. (2012). Defining the core Arabidopsis thaliana root microbiome. Nature, 488(7409), 86.

https://doi.org/10.1038/nature1123710.1038/nature11237

Maguire, J. D. (1962). Speed of germination-aid in selection and evaluation for seedling emergence and vigor. Crop Science, Madison, 2(1), Jan./Feb. 176-177. https://doi.org/10.2135/cropsci1962.0011183X000200020033x

Malamy, J. E., \& Benfey, P. N. (1997). Organization and cell differentiation in lateral roots of Arabidopsis thaliana. Development, 124(1), 33-44.

Mia, M. B., Shamsuddin, Z. H., \& Mahmood, M. (2010). Use of plant growth promoting bacteria in banana: a new insight for sustainable banana production. International Journal of Agriculture and Biology, 12(3), 459-467. http://dx.doi.org/ 09-279/SBC/2010/12-3-459-467

Moreira, M. A., Dantas, F. M., Santos, C. D., Oliveira, L. D., \& Moura, L. C. (2008). Produção de mudas de pimentão com o uso de pó de coco. Revista da Fapese, 4(2), 19-26.

Pais, A. K. L., da Silva, J. R., Alencar, F. C., Peixoto, A. R., de Souza, J. C., \& da Paz, C. D. (2016). Seleção de rizobactérias como promotoras de crescimento em melancia. Scientia Plena, 12(4). https://doi.org/10.14808/sci.plena.2016.040201

Pereira, O. C. N., Bertonha, A., Freitas, P. S. L., Gonçalves, A. C. A., Rezende, R., \& da Silva, F. F. (2003). Produção de alface em função de água e de nitrogênio. Acta Scientiarum. Agronomy, 25(2), 381-386. https://doi.org/10.4025/actasciagron.v25i2.1987

Pereira, S. I., \& Castro, P. M. (2014). Phosphate-solubilizing rhizobacteria enhance Zea mays growth in agricultural P-deficient soils. Ecological Engineering, 73, 526-535. https://dx.doi.org/10.1016/j.ecoleng.2014.09.060

Ramos, B. H., Silva, K. L. F., Coimbra, R. R., Chagas, D. B., \& Ferreira, W. D. M. (2015). Anatomy and micromorphometry of Caryocar brasiliense leaves. Rodriguésia, 66(1), 87-94. https://doi.org/10.1590/2175-7860201566106

Rêgo, M. C. F., Ilkiu-Borges, F., Filippi, M. C. C. D., Gonçalves, L. A., \& Silva, G. B. D. (2014). Morphoanatomical and biochemical changes in the roots of rice plants induced by plant growth-promoting microorganisms. Journal of Botany, 2014.

https://doi.org/10.1155/2014/818797

Saia, S., Rappa, V., Ruisi, P., Abenavoli, M. R., Sunseri, F., Giambalvo, D., ... Martinelli, F. (2015). Soil inoculation with symbiotic microorganisms promotes plant growth and nutrient transporter genes expression in durum wheat. Frontiers in plant science, 6, 815. https://doi.org/10.3389/fpls.2015.00815 
Sala, F. C., \& Costa, C. P. D. (2012). Retrospective and trends of Brazilian lettuce crop. Horticultura Brasileira, 30(2), 187-194.

https://doi.org/10.1590/S0102-05362012000200002

Schlindwein, G., Vargas, L. K., Lisboa, B. B., Azambuja, A. C., Granada, C. E., Gabiatti, N. C., \& Stumpf, R. (2008). Influência da inoculação de rizóbios sobre a germinação e o vigor de plântulas de alface. Ciência Rural, 38(3), 658-664.

https://doi.org/10.1590/S0103-84782008000300010

Sessitsch, A., Hardoim, P., Döring, J., Weilharter, A., Krause, A., Woyke, T. \& Hurek, T. (2012). Functional characteristics of an endophyte community colonizing rice roots as revealed by metagenomic analysis. Molecular Plant-Microbe Interactions, 25(1), 28-36. https://doi.org/10.1094/MPMI-08-11-0204

Shen, X., Hu, H., Peng, H., Wang, W., \& Zhang, X. (2013). Comparative genomic analysis of four representative plant growth-promoting rhizobacteria in Pseudomonas. BMC genomics, 14(1), 271. https://doi.org/10.1186/1471-2164-14-271

Shrivastava, P., \& Kumar, R. (2015). Soil salinity: a serious environmental issue and plant growth promoting bacteria as one of the tools for its alleviation. Saudi journal of biological sciences, 22(2), 123-131. https://doi.org/10.1016/j.sjbs.2014.12.001

Spaepen, S., \& Vanderleyden, J. (2011). Auxin and plant-microbe interactions. Cold Spring Harbor perspectives in biology, 3(4), a001438. https://doi.org/10.1101/cshperspect.a001438

Srivastava, S., Chaudhry, V., Mishra, A., Chauhan, P. S., Rehman, A., Yadav, A., ... Nautiyal, C. S. (2012). Gene expression profiling through microarray analysis in Arabidopsis thaliana colonized by Pseudomonas putida MTCC5279, a plant growth promoting rhizobacterium. Plant signaling \& behavior, 7(2), 235-245. https://doi.org/10.4161/psb.18957

Stahl, Y., \& Simon, R. (2010). Plant primary meristems: shared functions and regulatory mechanisms. Current opinion in plant biology, 13(1), 53-58.

https://doi.org/10.1016/j.pbi.2009.09.008

Teixeira Filho, M. C. M., Buzetti, S., Andreotti, M., Arf, O., \& Benett, C. G. S. (2010). Doses, fontes e épocas de aplicação de nitrogênio em trigo irrigado em plantio direto. Pesquisa agropecuária brasileira, 797-804.

https://doi.org/10.1590/S0100-204X2010000800004

Verboven, P., Herremans, E., Helfen, L., Ho, Q. T., Abera, M., Baumbach, T., ... \& Nicolaï, B. M. (2015). Synchrotron X-ray computed laminography of the three-dimensional anatomy of tomato leaves. The plant journal, 81(1), 169-182. https://doi.org/10.1111/tpj.12701

Viana, G. (2015). Bactérias aumentam produtividade do milho e reduzem adubos químicos Disponível em:<

https://www.embrapa.br/busca-de-noticias/-/noticia/2467608/bacterias-aumentam-produtivid ade-do-milho-e-reduzem-adubos-quimicos> Acesso em 07 de fev. de 2017 


\section{Macrothink}

Journal of Agricultural Studies

ISSN 2166-0379 2019, Vol. 7, No. 4

Yeats, T. H., \& Rose, J. K. (2013). The formation and function of plant cuticles. Plant physiology, 163(1), 5-20. https://doi.org/10.1104/pp.113.222737

Zhang, W., \& Yu, R. (2014). Molecule mechanism of stem cells in Arabidopsis thaliana. Pharmacognosy reviews, 8(16), 105. https://doi.org/10.4103/0973-7847.134243

Zhao, Y. (2012). Auxin biosynthesis: a simple two-step pathway converts tryptophan to indole-3-acetic acid in plants. Molecular plant, 5(2), 334-338.

https://doi.org/10.1093/mp/ssr104

\section{Copyright Disclaimer}

Copyright for this article is retained by the author(s), with first publication rights granted to the journal.

This is an open-access article distributed under the terms and conditions of the Creative Commons Attribution license (http://creativecommons.org/licenses/by/4.0/). 